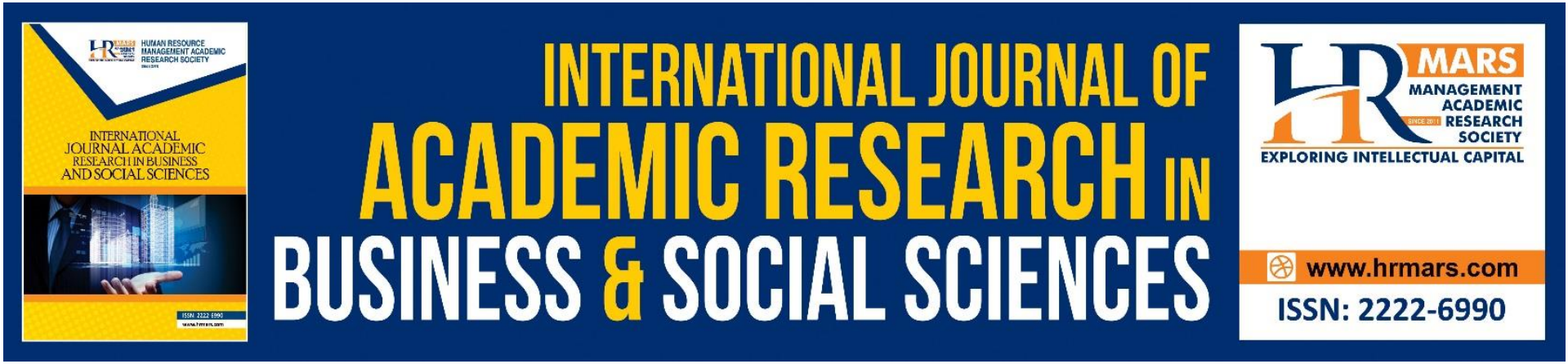

\title{
Utilizing Mobile Learning in Writing Skills in ESL Classroom
}

\section{Siti Sarah Binti Musthaffa Kamal, Azlina Abdul Aziz}

To Link this Article: http://dx.doi.org/10.6007/IJARBSS/v11-i12/11166 DOI:10.6007/IJARBSS/v11-i12/11166

Received: 24 October 2021, Revised: 26 November 2021, Accepted: 10 December 2021

Published Online: 28 December 2021

In-Text Citation: (Kamal \& Aziz, 2021)

To Cite this Article: Kamal, S. S. B. M., \& Aziz, A. A. (2021). Utilizing Mobile Learning in Writing Skills in ESL Classroom. International Journal of Academic Research in Business and Social Sciences, 11(12), 2206-2220.

Copyright: (c) 2021 The Author(s)

Published by Human Resource Management Academic Research Society (www.hrmars.com)

This article is published under the Creative Commons Attribution (CC BY 4.0) license. Anyone may reproduce, distribute, translate and create derivative works of this article (for both commercial and non0-commercial purposes), subject to full attribution to the original publication and authors. The full terms of this license may be seen

at: http://creativecommons.org/licences/by/4.0/legalcode

Vol. 11, No. 12, 2021, Pg. 2206- 2220

http://hrmars.com/index.php/pages/detail/IJARBSS

JOURNAL HOMEPAGE

Full Terms \& Conditions of access and use can be found at http://hrmars.com/index.php/pages/detail/publication-ethics 


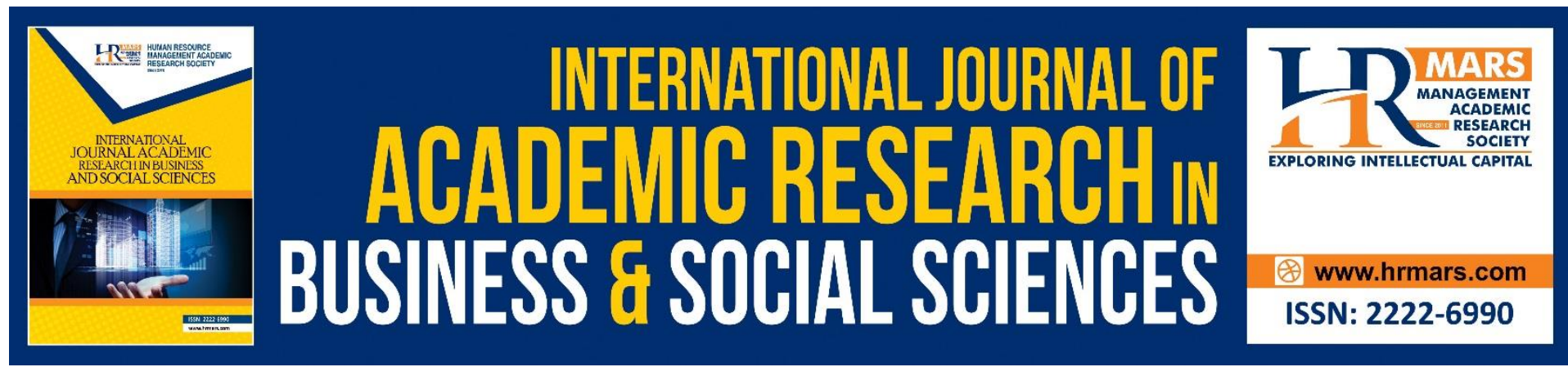

\title{
Utilizing Mobile Learning in Writing Skills in ESL Classroom
}

\author{
Siti Sarah Binti Musthaffa Kamal, Azlina Abdul Aziz \\ Faculty of Education, University Kebangsaan Malaysia, 43600 Bangi, Selangor, Malaysia \\ SMK Putrajaya Presint 5 (1), 62000 Putrajaya, Wilayah Persekutuan Putrajaya, Malaysia \\ Email: p106126@siswa.ukm.edu.my
}

\begin{abstract}
This paper portrayed a systematic review of relevant published studies on how mobile learning tools can help ESL primary school learners to enhance the interaction among their peers or teachers. It discussed the impact of utilising the mobile learning in writing skills of ESL school learners. The use of mobile learning tools brings so much impact on the good and bad sides for all people who are involved. Apart from that, since pandemic of COVID-19 been aroused around the world, it is definitely need to change the method of conversational method to advanced method on teaching and learning of English in writing skill which indeed to involved mobile learning as one of the modern platform which is easy and free to utilise it. This systematic review of literature (SLR) is focusing on the effectiveness of utilising mobile learning in writing skill among English second language learners and perspective of the learners on the mobile learning utilisation in English writing language learning. There were 21 articles pertaining to the utilising mobile learning in writing skill among ESL learners which were screened from the ERIC and ScienceDirect databases by using the review methodology of Preferred Reporting Items for Systematic Review and Meta-Analyses (PRISMA). The results derived from the articles throughout the year 2021 demonstrated that the most used research design to accumulate the effectiveness of mobile learning and learners' perspective on its utilisation in writing skill among ESL learners. In general, the findings illustrated factors influencing the effectiveness of mobile learning, presented its benefits and showed positive impact on the English language learners' academic performance with the support of appropriate teaching approaches, meaningful learning and effective learning environments and due to that reason, ESL learners showed positive perspectives towards mobile learning. The result of the findings suggests future study to investigate the perspectives of parents on the effectiveness of mobile learning in English language writing among ESL learners and address relevant issues on the challenges in implementing mobile learning such as network connectivity and availability of mobile devices and its usability.
\end{abstract}

Keywords: Mobile Learning, Effectiveness, Perception, Writing Skill, ESL Classrooms, Systematic Literature, PRISMA 


\section{Introduction}

In this recent global and era of pandemic of COVID-19 aroused in the world, utilising mobile learning in teaching and learning would be one of the vital methods to survive in teaching and learning era to avoid the ongoing pandemic rampantly widespread. Thus, mobile learning has gained a plethora of attention and choice that would be preferred to employ as a mediator in teaching and learning sessions. According to Sung et al., 2016, as cited in Ng et al., 2020, to be precise, the integration of mobile learning turned into a vital reinforcement technique towards activating motivation and engagement and implementation of various content delivery strategies. This study inspired from the recently introduced school term, that is home-based learning (HBL). This alternative is in an effort to keep the education ongoing even during the Movement Control Order (MCO) where face-to-face classroom teaching and learning were obstructed due to COVID-19.

The on the rise use of mobile learning among educators was recognised globally which then eventually its effectiveness in improving particularly the academic performance of language learners in writing skill and developing their knowledge has gained attention of the researchers and been questioned. This review of systematic literature with respect to the utilisation of mobile learning happened to be a method that effectively provides a better understanding of learners' perspectives on mobile learning even though it was predictable. Accordingly, this study was to investigate the effectiveness of mobile learning in improving English language writing skills among ESL learners. This study is also to investigate learners' perspective towards using mobile learning in writing skill. The findings of this study are expected to clarify the mobile learning utilisation, effectiveness towards improving learners' writing skills and how the use of mobile learning in writing skills is perceived by the ESL learners. The findings of this review are expected to clarify that the utilisation of mobile learning is one of the key factors which is effective in improving writing skills among ESL learners and will give shape and meaning to the perspectives of educators and learners on the use of mobile learning in improving writing skills. The purpose of this review will be examined in depth in the following sections, followed by the method in conducting this systematic literature review using the PRISMA 2021 checklist.

\section{Definition of Mobile Learning}

The extremely increasing popularity of mobile devices has driven to a new reality of mobile learning applications or Mobile-assisted language learning in language education (Pham et al., 2021). Technology tools have been incorporated in instructional settings by numerous researchers including practitioners ever since mobile phones are becoming more universal (Park, 2011). Playing almost the same role as other ICTs devices, mobile phones make distance or virtual learning possible as it is accessible and convenient to use at any time and most people can afford it. Mobile learning is a shift from computer-assisted language learning around the 1980s. Nevertheless, the mobile devices users are higher in number compared to computer or laptop users and it is significantly the best approach to integrate mobile learning in ESL or EFL classrooms (Al-Shehab, 2020).

According to Samsiah et al., 2013; as cited in Arlina et al., 2021, besides the fact that mobile phones are owned by the majority, it has been used by many users because of its mobility or handiness and interconnectivity. Based on the study by Valk et al, 2020, as cited in Arlina et al., 2021, it found that about $90 \%$ of learners below 18 years old gained access to mobile 
technology since mobile phones are considered to be most appropriate for education advancement compared with other ICT types. Hence, it justified the change to mobile learning from educational technologies. Although the use of mobile phones in teaching and learning has not always been smooth and an easy transformation, the promising compatible applications available such as Vlearn, Kahoot! Quizziz, Telegram, Whatsapp, Google Classroom and so forth have been supplementing learning with simple, interesting and effective content. Nazari et al (2021) states that the auspicious artificial intelligence writing on mobile phones facilitate learners' learning and enhance their writing skills which are not easy to be learned through conventional practices.

The Malaysians government has declared a new school term called home-based teaching and learning after taking into consideration the ongoing pandemic situation which resulted in the closure of school in the whole state. As a result, this home-based teaching and learning has opened the way and provided a solution to make education accessible under any conditions or circumstances. Hence, nowadays, a mobile phone is a must-have device for every single learner for learning purposes. Therefore, in an effort to ensure that no learner will be left behind, subsidy initiatives were initiated by the government to help underprivileged families and learners with free mobile devices, data plans and virtual learning content available on FrogPlay Mobile App. This means that mobile phones make learning and revising easy to be accessed through available mobile applications.

\section{Type of Mobile Learning}

Identifying an alternative to monotonous teaching and learning is a wise move by the government as in an effort to maximise engagement, develop literacy skills and goal-directed behaviors in learners which are the essential factors influencing learners' learning and achievement. As teachers who are upholding the passion in teaching would consider technology integrated in their instructional tool to generate easy and effective learning. There are various online creative writing applications that can be integrated in educators' teaching. Artificial intelligence writing tools which also available on the mobile are designed to potentially aid learners in enhancing their writing skills and are easy to learn compared to traditional teaching approaches (Nazari et al., 2021).

Apart from that, mobile learning is not only limited to the classroom setting but it provides boundless opportunities for learners to enhance language skills. There are numerous mobile learning applications available to accommodate learners' needs and supplement them with learning content covering the core subjects including English which are mapped to the Malaysian education syllabus, from primary to secondary schools such as FrogPlay and Vlearn mobile apps. According to Toti, 2018, as cited in Jong \& Hua (2021), the utilisation of web tools, Padlet is able to give learners the opportunity to discuss their ideas for any designated tasks wherever possible. For that reason, this web digital tool which is a versatile pedagogical tool that enables learners' feedback to be gathered by the educators and available to access on different devices like smartphones and computers (Jong \& Hua, 2021).

Meanwhile, according to Tafazoli et al., 2014, as cited in Perveen, 2021, suggested word cloud as a useful application for second language learners to intensify all language skills including the integrated skills. This application can reduce the pressure in second language learning through the exciting multiple literacies application where learners can enhance their 
ownership in the learning process and their artwork as well as comprehension and production of language (Perveen, 2021). The interactive and dynamic experience from Web 2.0 applications such as YouTube, Facebook and Edmodo including other social media platforms proved to be effective and positively impact learners' learning (Jong \& Hua, 2021).

According to Filatove, 2016, as cited in Perveen, 2021, the use of word clouds would be considered as an effective method to speed up the time for reading, summarizing, spelling lessons, make meaning and collocations, enhance vocabulary banks and elements of rhetorical writing. In addition, according to Elboshi (2021), web-based programs enable learners to obtain information and knowledge from all areas of study, hence the language learning, particularly writing, is remarkably supported. According to Thornton \& Horse, 2005; as cited in Bachore, 2015, learning can be carried out through mobile devices with the implementation of web-based video for learning idioms while mobile-based platforms like Email for stimulating learning of vocabulary. Apart from that, according to Ahmed (2016) the constructivism theory will keep in pace and the high development of scaffolding from the teacher or peers will take place when students collaboratively write in Telegram.

\section{Writing Skill}

One of the four basic skills in English language next to reading, speaking and listening is writing. It is a purposive exercise by a writer in which the content is intended to the target reader through the use of letters, signs and symbols (Elboshi, 2021). Similarly, Kabigting (2020) states that writing can be a means for communicating ideas and information. Thus, it is the primary skill that must be trained by ESL learners. According to len et al., 2017, writing is broadly recognised as a critically crucial skill in English language learning for the non-native since this inclusive skill facilitates in intensifying all core components used in writing. At the end of standard 6, writing is tested in the standard evaluation system of primary education i.e. Primary School Assessment Test (UPSR) and due to its components, writing is considered as an extremely difficult subject amongst the examinees. Similarly, according to Chan at al., 2018, as cited by Suhaimi, 2019, the English language learners within children in Malaysia shows deterioration as not much improvement exhibited in their English particularly in writing competency even though they have been learning English since early childhood education.

In addition, according to Yusuf \& Hamidun, 2015, vocabulary and grammar rules are some main components which are needed to help to put words into meaning and enrich writing with correct grammar used with the consistent practise of writing which also helps learners to solidify their writing skills. However, the majority of the students found that writing is the biggest problem and hardest skill since their writing is not getting any better. To have clear and effective writing proficiency is regarded as the key part of written communication skills within the learners of all educational levels (Upadhayaya, 2019).

Ong et al (2020) describes the different types of genres in writing tasks assigned to the learners, namely informal letter, narrative, descriptive, argumentative and report writing. As for writing argumentative essays, learners should legitimise their personal viewpoint. Moreover, according to Chon (2021) the expository genre writing use for evaluating the proficiency in writing was considered as valid assessment as it is very sensitive to examine the writing ability of learners where the cognitive ability at higher level, assessing evidence, explaining an idea, and presenting an argument. Meanwhile, in the study conducted by 
Husnawati (202), found that learners were better at composing complex sentences by using linkers, recognising grammatical errors accurately, using proper choices of lexical and means of writing and way of organizing information from different writing genres.

In addition, the skill in writing involves the ability to deliver their practice, thought, grammatically correct text and richer vocabulary as each one of them has their unique way of thinking which makes them possess different perspectives for demonstrating it (Kabigting, 2020). It requires learners to have a great level of thinking skills in order to be able to produce critical writing because they must do more than just grasping the content knowledge and cultivate critical thinking skills, therefore, topic comprehension, thought revolution and development of critical thinking skills can be enhanced through writing assignments (Singh et al., 2020). In a study conducted by Kabigting, 2020, found that the implementation of RAFTs strategy which refers to Role of writer, target Audience, Format of written product and Topic writing plus with strong verbs used evoked the positive attitudes from learners besides increased motivation and activated engagement in learning recount writing.

As for the low ability learners especially, writing is perceived as a tough task which affects their interest in learning writing skills. Thus, they ended up plagiarising their friends' works or not writing anything at all on the assigned writing activities (Jong \& Hua, 2021). Therefore, many studies suggested the use of mobile learning to facilitate language skills. Arlina et al (2021) suggested that the argumentative writing ability can be expanded with the use of mobile learning because it is accessible at all time and any place. Thus, it facilitates learners to experience learning collaboratively without concern on time and place to enhance their writing ability. According to Lee and Kim, 2013, as cited in Zaki \& Yunus, 2015, mobile phones can also be used as a tool in learning that improves writing skills among English as Foreign Language learners. Gharehblagh \& Nasri (2020) stated that the fact from related studies in addressing mobile technology application in distinct contexts of developing writing illustrated that writing certainly has a collaborative environment and mobile phones able to supplement educators and learners with practical implications that simplify the process. Seow, 2002, as cited in Husnawadi, 2021, states that since writing requires skills in generating and organizing ideas and turning them into coherent and concise intelligible texts, mastery of writing skills has become a major cognitive-linguistic problem.

\section{The Aim of Current Systematic Review}

This systematic review addresses concerns of how ESL primary school students are facilitated in improving their writing skills in English language learning through mobile learning. It is executed in a view to comprehend the ESL learners' perspectives on the use of mobile learning in English language writing skills. Prior mentioned, the learners' perspectives in the use of mobile learning and its effectiveness in improving English language skills particularly on writing along with enhancing learners' academic achievement and expansion of knowledge are highlighted to evoke the realisation of associate stakeholders towards the possible potential of aforesaid online-based learning. The following questions were reviewed in this systematic literature review:

1) How does mobile learning assist ESL primary school learners in improving their writing skills? 
2) What is the perception of using mobile learning towards ESL primary school learners in writing skill?

\section{Method}

PRISMA 2021 checklist, an acronym referring to Preferred Reporting Items for Systematic Review and Meta-Analyses has been used to conduct this review. It encompasses 21 items for improving review transparency. This review implements a comparative research method, comparison of descriptive in particular. Since this paper targets to describe and clarify further on the effectiveness of mobile learning in improving English writing skills among ESL learners and their perspectives towards mobile learning utilisation in English writing, thus, this paper serves as a systematic effort to illustrate how mobile learning assists ESL students in improving their writing skills and perceptions of the use of mobile learning towards ESL students in writing skills.

This paper has conceptually analysed the critical components of how mobile learning assists ESL primary school learners in improving their writing skills and the perception of using mobile learning in writing skill among ESL primary school learners by surveying a selected array of articles relevant to utilisation of mobile learning in writing skill among ESL learners. The process began with identifying relevant articles to the use of mobile learning in the English writing skills among ESL learners within the coverage from ERIC and ScienceDirect databases. The whole process has undergone four different phases, namely the phase of identification, screening, eligibility, and finally, inclusion.

\section{Prisma}

\section{$1^{\text {st }}$ Phase : Identification Phase}

The referred databases were ERIC and ScienceDirect to conduct this review, and the limit range of search was from 2021. ERIC, an acronym referring to Education Resources Information Center provides searchable comprehensive education research and information, in other words it serves as a global gateway to over 1000 journals from multi-research and instructional materials. As for ScienceDirect, it is a full-text database offering journals, articles and book chapters from peer-reviewed journals which use a federated search mechanism. Significant keywords were entered to look up for the articles are demonstrated in Table 1. As shown in Table 2, supplementary information added during the searching as to determine the relevant articles based on the criteria set by the researchers.

able 1: The keywords used to search for relevant articles.

\begin{tabular}{|l|l|l|}
\hline Database & ERIC & ScienceDirect \\
\hline Keywords & $\begin{array}{l}\text { Utilising mobile learning in writing } \\
\text { skill among ESL learners, } \\
\text { effectiveness of mobile learning, } \\
\text { learners' perspective of the use of } \\
\text { mobile learning }\end{array}$ & $\begin{array}{l}\text { Utilising mobile learning in } \\
\text { writing skill among ESL learners, } \\
\text { effectiveness of mobile learning, } \\
\text { learners' perspective of the use } \\
\text { of mobile learning }\end{array}$ \\
\hline
\end{tabular}


Table 2: The criteria for inclusion and exclusion.

\begin{tabular}{|l|l|l|l|l|l|}
\hline Criterion & Article type & Language & Year & Peer-reviewed & Perspective \\
\hline Inclusion & Journal Article & English & 2021 & Peer-reviewed & $\begin{array}{l}\text { Students, } \\
\text { Teachers } \\
\text { Educators }\end{array}$ \\
\hline Exclusion & $\begin{array}{l}\text { Systematic } \\
\text { review, } \\
\text { proceedings,bo } \\
\text { ok, book } \\
\text { chapter bon-English }\end{array}$ & $<2021$ & Non-peer reviewed & Parents \\
\hline
\end{tabular}

\section{$2^{\text {nd }}$ Phase : Screening}

Any duplicates discovered during searching for the relevant articles to the area of research in both ERIC and ScienceDirect were terminated correspondingly, The remaining articles were re-examined to assure they met the researchers' criteria.

\section{$3^{\text {rd }}$ Phase : Eligibility}

In this phase, collected articles' eligibility had undergone a checking process in order to meet the stated criteria in the inclusion section as shown in Table 2. It is essential to consider the significance of this phase as to ensure the data acquired in this review were reliable and high quality content.

\section{$4^{\text {th }}$ Phase : Exclusion}

Following the third phase of checking the eligibility of the articles, the articles left were omitted from this study since they were not counted in the journal articles and not from the year 2021. The non-peer reviewed and non-English language publications were also omitted together with the articles on the parents' perspective on the research area. As important as the eligibility phase, the exclusion phase was crucial in ensuring the quality of the data acquired by the researchers. Figure 1 depicts the flow of process from different phases of a systematic review. 
Figure 1. The four-phase diagram of the process in the selection of research articles.

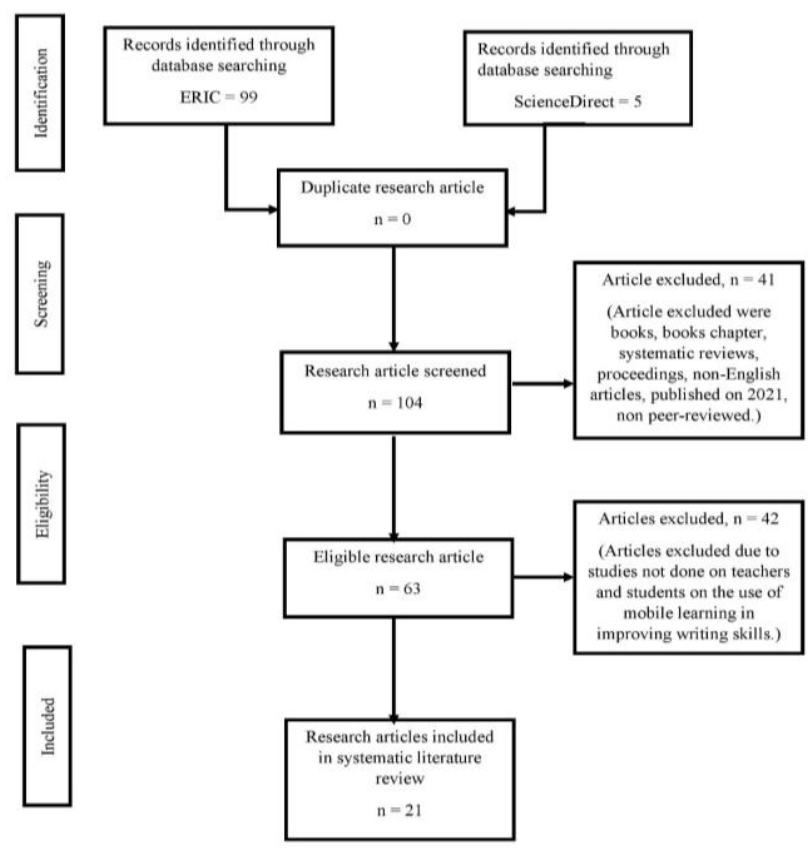

\section{Results of Systematic Review}

The identified research articles from the process of selection will be further discussed in this segment. Attributable to the area of respective studies, there were 21 appropriate articles that were to be reviewed in this study after undergoing all significant phases of selecting eligible articles. Two (2) main aspects can be found from the respective articles, mainly the effectiveness of mobile learning in improving writing skills among ESL learners and perception of learners towards the use of mobile learning in writing skills. The number of research articles related to the systematic review which derived from ERIC and ScienceDirect were categorised according to the aspects as shown in Table 3 and Figure 2.

Table 3: The number of research articles studying the use of mobile learning in aspects of effectiveness and perception of learners in use of mobile learning in improving writing skills among ESL learners.

\begin{tabular}{|l|l|}
\hline Aspects & Number of Research Articles \\
\hline Effectiveness & 13 \\
\hline Perspectives & 8 \\
\hline
\end{tabular}


Figure 2: No. of related publications in the research areas

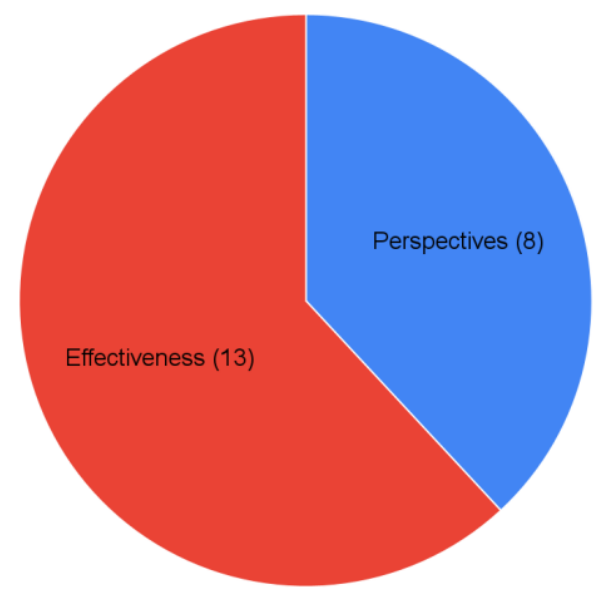

\section{Discussion}

\section{Learner's Perspectives on the use of Mobile Learning}

Some learners are unprepared for changes and unfamiliar with how to navigate and use mobile applications in language learning which then reluctant to incorporate technology in learning as they think mobile phones are only meant for socialising not for learning purposes. According to Folk, 2016, as cited in Al-Shehab, 2020, there are some reports claiming that learners are hesitant to use mobile devices in the process of learning and the rest were comparing implementation of mobile use in new writing methods with putting pen to paper. However, with more exposure on how mobile devices can improve language learning would motivate learners to utilise it for educational purposes which in the meantime would help them uncover its possibility to ease the process of learning (Al-Shehab, 2020).

Kintu et al., 2017, as cited in $\mathrm{Ng}$ et al., 2020 stressed the contributing factors towards increasing learners' performance academically and effectiveness of mobile learning. That is, learners' affective filter, instructional design and outcomes of the learning, thus the preparation to meet the need of learners and appropriate framework of learning is necessary. According to Deni \& Zainal, 2018, as cited in Bonaventure et al., 2021, states that learners' perceptions towards the benefits of technology can be positively developed through fostering meaningful learning.to encourage them to utilise technology tools in learning.

It is crucial to recognise learners' preferences pertaining to technology use in general and to understand particularly learners' perception on the effectiveness of mobile assisted language learning materials in accommodating the acquisition of language (Kohnke \& Ting, 2021). Apart from that, it is necessary for the educators to spot learners who are struggling at an early stage, so that any possible action to improve learners' retention and success can be taken. According to Pikhart (2021), it is therefore essential to respond to the needs of generation $Z$ through the execution of machine and deep learning, artificial intelligence as well as advanced human-computer interaction model-based learning as this generation is anticipating the advantages they hope to gain naturally from these language learning applications..

In addition, according to Lucas Kohnke (2021), the learners perceived that the tool was helpful and encouraging in building and expanding their knowledge of disciplinary vocabulary. Meanwhile, numerous applications are designed to facilitate learners to work out on their grammar, and there are tools that can be used to check for grammatical errors and learners 
perceive it as an effective tool to improve their sentence level grammar and this is one way of the product approach can be implemented through mobile devices (Zaki \& Md Yunus, 2015). As reported by Study (2021), in the perspective of the learners, online learning platforms need self-regulation and attachment regardless of the way it is executed. It is essential that learners are aware of the significance and advantages of online learning to supplement their individual development.

According to Bonaventure et al., 2021, the learners demonstrated a positive attitude towards the use of technological tools in the process of language learning as committed in completing their assessment activity on Padlet dedicatedly. In the meantime, Perveen (2021) reported positive opinion on study on the perception of learners and educators on using word clouds as supporting educational tools in online learning mode of EFL as they discovered a force of motivation to create engaging learning experiences.

Others perceived that the possibility of downloading a full words list along with the pronunciation instruction on their mobile phone when they were stuck was significantly helpful in expanding their subject-specific vocabulary and useful in motivating them to continue utilising the application (Kohnke \& Ting, 2021).

\section{The Effectiveness of Mobile Learning in Improving Writing Skill}

In order to effectively facilitate learners' language learning, the approach and tools in learning adopted must be considering the learners' affective filter such as emotion and feeling. According to Su et al (2019), as cited in Nazari et al (2021), the integration of artificial intelligence was effective to emerge learners' emotions positively and the negative emotions were diminishing.

According to $\mathrm{Ng}$ et al (2020), technological advancement has contributed to the gradual transformation towards language acquisition skills method among the learners which at the same time influenced the teaching strategies that the educators adopted. Undeniably, technological advancement has come into effect in education institutions, specifically in the classroom. Thus, the various open source applications and other helpful technology tools can be accessed by the learners and educators to intensify learning.

The interactive and dynamic experience from Web 2.0 applications such as YouTube, Facebook and Edmodo including other social media platforms proved to be effective and positively impact learners' learning (Jong \& Hua, 2021). The definite possibility of the effective teaching and learning method using mobile learning cannot be spotted from the previous literature and there is a need for appropriate research to be carried out on the extent to which guided mobile learning can be effective and its possibility in impacting learners' achievement (Ng et al., 2020). According to Chon (2021) the use of MT reveals its benefits in the writing products of low ability learners who committed little lexico grammatical mistakes and generated refined corrections.

As reported by Cahyono and Astuni, 2019, as cited in Al-Shehab, 2020, the association of approach of process writing with video-based mobile learning was effective in intensifying the writing skills of learners. Thus, it is highly suggested that mobile devices assist and intensify teaching and learning of writing with its ability to cultivate learners' motivation. On the other hand $\mathrm{Ng}$ et al (2020) states that it is necessary to guide learners in both aspects of 
technological and methodological, instead of just providing mobile phones for the learners because some of them may have insufficient knowledge and exposure to find solutions to problems during the process in adopting unfamiliar technologies.

ESL writing learners given the opportunities to utilise the desired language expressively to communicate and interact with one another at their convenience time and freely with the application of social networking and web blogings compared to restricted content of lesson that is mapped to the curriculum and insufficient teaching and learning hours in the classroom setting (Elboshi, 2021). According to Holstein et al., 2017; Reeves et al., 2017 ac cited in Nazari et al., 2021, mobile as technology tool giving educators more flexibility in their teaching and continuous mini-assessment especially through social network.

There are particular features of mobile learning that can possibly provide practicable enhancement by building language learning accessible for everyone at their own availability (Kukulska-Hulme et al., 2015, as cited in Gharehblagh \& Nasri, 2020). With a great numbers of substantial features that can be utilised by educators in an effort to upgrade the process of learning, especially in the English writing context (Al-Hamad et al., 2019; Jassim \& Dzakiria, 2019; Siddique \& Nair, 2015, as cited in Al-Shehab, 2020).

\section{Teachers Perspectives on How Mobile Learning in Improving Writing Skills}

Malaysian educators acknowledged the difficulties faced by the ESL learners in developing their writing specifically in using conventions and punctuations properly. Therefore, educators are required to congruence their teaching strategies with the learners' need to deal with the writing issues (Nair \& Sanai, 2018). While there are educators who support the idea of motivating students with the use of mobile devices to facilitate students in the classroom learning, however, on the contrary, some educators reject this practice entirely ( $\mathrm{Ng}$ et al., 2020). According to Li et al (2021), as in accordance with teachers, various technology-based integrations and programs supplement learners' learning in improving essential skills of literacy. For instance, learners take part in essential skills of narrative essays when producing graphic novels where they work on complicated task that require continuous amendment, critical thinking and assessing response while producing graphic novels, for instance, creating persona portrayals for the illustrations.

Meanwhile, According to Kohnke \& Ting, 2021; Perveen (2021) reported positive opinion on study on the perception of learners and educators on using word clouds as supporting educational tools in online learning mode of EFL as they discovered a force of motivation to create engaging learning experiences. According to (Jong \& Hua, 2021). Teachers are able to assess the writing progress of learners through Padlet use in learning and give comments or respond instantly.

\section{Conclusion}

The Systematic Literature Review has revealed the final result of reviewed of all the articles, it is recommended that teachers of English language should be actively use a mobile learning platform as a mediator in improving a writing skills which definitely viewed the effectiveness and the perception of learners in utilisation of mobile learning as one of the method in improving writing skills among ESL learners. Thus, the nature of mobile learning itself contributes to an exciting learning experience which affects the learner's performance in 
school. Instead of that, this systematic review also interprets the effectiveness of mobile learning which portray the easiness and flexibility of educators in order to teach writing skills through mobile learning method.

The contributions that have been made by this systematic literature review article was to summarize and reviews the component on how to utilize the mobile learning in improving writing skills among ESL learners. Besides that, the integration of mobile learning based on the legitimate sources and literature reviews are indeed to be counted and accumulate for the future references to validate the integration of mobile learning in the writing skill among ESL Learners for the future endeavor.

\section{Challenges \& Limitations}

There are a few limitations that are acknowledged in this study which would be significant for forthcoming or further study. Firstly, due to the time allotment, there were only 21 articles from ERIC and ScienceDirect that were reviewed. Suppose the research has been broadened and investigated more opinions and views, the result might be gratifying and reinforcing better interpretation of the findings from the study. In addition to that, there could be other potential articles from SCOPUS and Google Scholar databases too that may provide more articles regarding the topic that has been discussed. Finally, the researcher of this study was unable to make contact face to face with any of the authors of the articles which had been reviewed in this study due to the time constraint.

\section{Implications \& Recommendations}

Through this literature of systematic reviews, has emerged the potential of the utilisation of mobile learning in improving English writing skills among ESL learners and brought new perspectives among ESL learners in the education field, specifically in English teaching and learning. Educators and learners have given an auspicious perception on the utilisation of mobile learning to improve writing skills. One of the concerns during the review of the articles are the issues of lack of affection for physiology or no eye contact between the educators and learners hence unable to check learner's progress in group activity in real time. These issues need to be addressed by future studies to enlighten the effectiveness of mobile learning in and promoting mobile learning as a tool and platform in improving writing skills among ESL learners.

\section{References}

Al-khazraji, A. (2019). Analysis of discourse markers in essays writing in ESL classroom. International Journal of Instruction, 12(2), 559-572.

Al-Shehab, M. A.-S. (2020). The Role of Mobile-assisted Language Learning (MALL) in Enhancing the Writing Skills of Intermediate IEP Students: Expectations vs Reality. Language Teaching Research Quarterly, 20, 1-18.

Bachore, M. M. (2015). Language Learning through Mobile Technologies: An Opportunity for Language Learners and Teachers. Journal of Education and Practice, 6(31), 50-53.

Chon, Y. V., Shin, D., \& Kim, G. E. (2021). Comparing L2 learners' writing against parallel machine-translated texts: Raters' assessment, linguistic complexity and errors. System, 96, 102408.

Elboshi, A. (2021). Web-Enhanced Peer Feedback in ESL Writing Classrooms A Literature Review. English Language Teaching, 14(4), 66. 
Gharehblagh, N. M., \& Nasri, N. (2020). Developing EFL elementary learners' writing skills through mobile-assisted language learning (MALL). Teaching English with Technology, 20(1), 104-121.

Hammou, Y. A. (2019). International Journal of Language and Literary Studies. 1(3), 1-19.

Husnawadi. (2021). Students' Perceptions of Flipped Classroom-Mediated Task: Insights From an Indonesian Post-Earthquake Efl Writing Pedagogy. Teaching English with Technology, 2021(1), 8-28.

Jong, B., \& Kim Hua, T. (2021). Using padlet as a technological tool for assessment of students' writing skills in online classroom settings. International Journal of Education and Practice, 9(2), 411-423.

Kabigting, R. (2020). Utilizing the RAFT Strategy: Its Effects on the Writing Performance of Filipino ESL Learners. JET (Journal of English Teaching), 6(3), 173-182.

Kim, H. J., Yi, P., \& Hong, J. I. (2020). Students' academic use of mobile technology and higherorder thinking skills: The role of active engagement. Education Sciences, 10(3).

Kohnke, L., \& Ting, A. (2021). ESL students' perceptions of mobile applications for disciplinespecific vocabulary acquisition for academic purposes. Knowledge Management and ELearning, 13(1), 102-117.

Li, J., Brar, A., \& Roihan, N. (2021). The use of digital technology to enhance language and literacy skills for Indigenous people: A systematic literature review. Computers and Education Open, 2(August 2020), 100035. https://doi.org/10.1016/j.caeo.2021.100035

Lim, T. M., \& Yunus, M. M. (2021). Teachers' Perception towards the Use of Quizizz in the Teaching and Learning of English: A Systematic Review. Sustainability, 13(11), 6436.

Nair, S. M., \& Sanai, M. (2018). Effects of utilizing the stad method (Cooperative learning approach) in enhancing students' descriptive writing skills. International Journal of Education and Practice, 6(4), 239-252.

Nazari, N., Shabbir, M. S., \& Setiawan, R. (2021). Application of Artificial Intelligence powered digital writing assistant in higher education: randomized controlled trial. Heliyon, $7(5)$, e07014.

Ng, S. F., Azlan, M. A. K., Kamal, A. N. A., \& Manion, A. (2020). A quasi-experiment on using guided mobile learning interventions in ESL classrooms: Time use and academic performance. Education and Information Technologies, 25(6), 4699-4719.

Ong, E. T., Singh, T., Singh, M., Kaur, R., \& Singh, A. (2020). How to cite this article: Singh, C. K. S., Gopal, R., Tek, O. E., Masa Singh, T. S., Mostafa, N. A., \& Ambar Singh R. K. (2020). ESL teachers' strategies to foster higher-order thinking skills to teach writing. 17(2), 195-226.

Park, Y. (2011). A pedagogical framework for mobile learning: Categorizing educational applications of mobile technologies into four types. International Review of Research in Open and Distance Learning, 12(2), 78-102.

Perveen, A. (2021). Use of word clouds for task based assessment in asynchronous e-language learning. Mextesol Journal, 45(2), 0-1.

Pham, L. L. N., Nguyen, H. T., \& Le, V. T. K. (2021). Triggering Students' Learning Autonomy Using the Combination of M-Learning and Gamification: a Case Study At Nguyen Tat Thanh University. Teaching English with Technology, 21(2), 66-91.

Pikhart, M. (2021). Human-computer interaction in foreign language learning applications: Applied linguistics viewpoint of mobile learning. Procedia Computer Science, 184, 92-98.

Study, O. (2021). Supplementary Online Study Platform for an Oral Communication Skills Course : Implementation, Evaluation and Suggestions. 15(1), 90-117. 
Syahrin, S., \& Abdalla Salih, A. (2020). An ESL Online Classroom Experience in Oman during Covid-19. Arab World English Journal, 11(3), 42-55.

Xiao, Y., \& Watson, M. (2019). Guidance on Conducting a Systematic Literature Review. Journal of Planning Education and Research, 39(1), 93-112.

Zakaria, M. I., Mistima Maat, S., \& Khalid, F. (2019). A Systematic Review of M-learning in Formal Education. International Journal of Innovation, Creativity and Change.

Zaki, A. A., \& Md Yunus, M. (2015). Potential of mobile learning in teaching of ESL academic writing. English Language Teaching, 8(6), 11-19. 